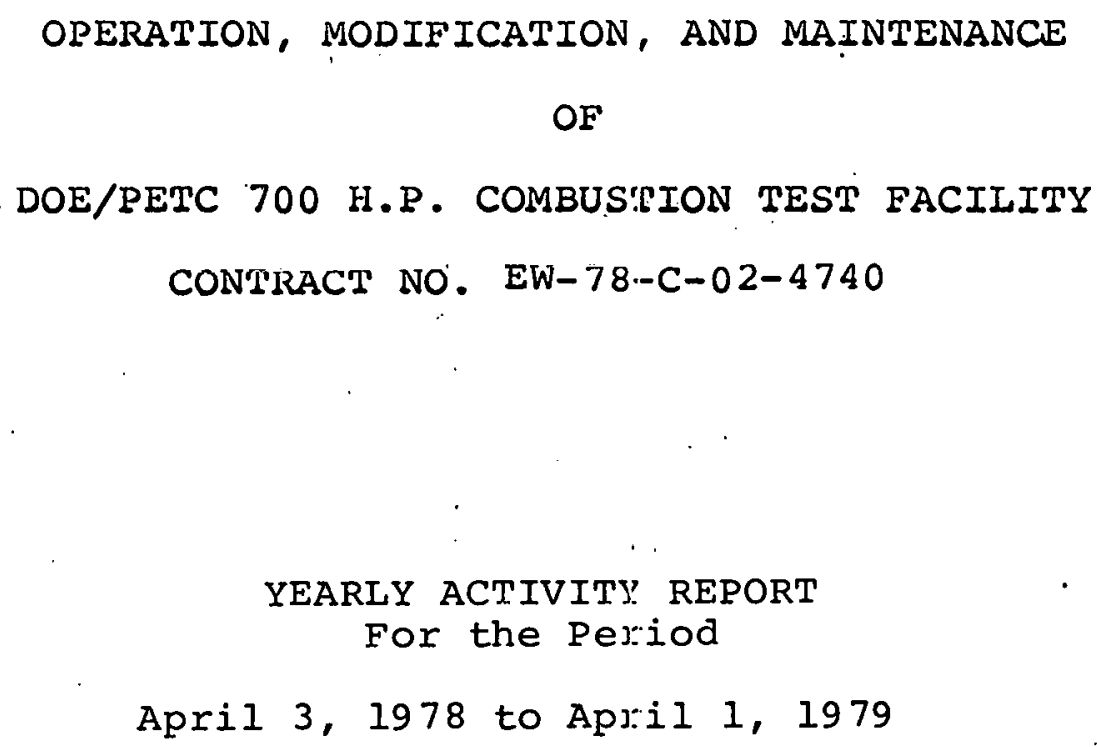

\title{
Prepared for the United States
}

Department of Energy

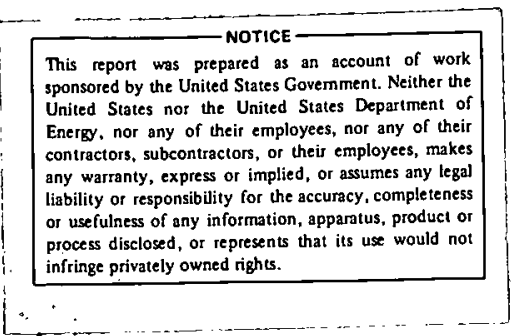




\section{DISCLAIMER}

This report was prepared as an account of work sponsored by an agency of the United States Government. Neither the United States Government nor any agency Thereof, nor any of their employees, makes any warranty, express or implied, or assumes any legal liability or responsibility for the accuracy, completeness, or usefulness of any information, apparatus, product, or process disclosed, or represents that its use would not infringe privately owned rights. Reference herein to any specific commercial product, process, or service by trade name, trademark, manufacturer, or otherwise does not necessarily constitute or imply its endorsement, recommendation, or favoring by the United States Government or any agency thereof. The views and opinions of authors expressed herein do not necessarily state or reflect those of the United States Government or any agency thereof. 


\section{DISCLAIMER}

Portions of this document may be illegible in electronic image products. Images are produced from the best available original document. 
The General Electric Company (MATSCO) was awarded the contract to operate, modify, and maintain the DOE/PETC $700 \mathrm{H} . \mathrm{P}$. Combustion Test Facility. The $700 \mathrm{H} . \mathrm{P}$. Combustion Test Facility was designed and built by the Department of Energy at Pittsburgh Energy Research Center and its ultimate success is the responsibility of DOE/PETC. G. E. CO/MATSCO will provide support to assist in the goal of successful operation of this pilot plant facility. The primary objective of the DOE/PITC $700 \mathrm{H} . \mathrm{P}$. CTF is to establish

a the practicality of coal oil slurry combustion as a technically. economically, and environmentally feasible retrofit technology.

WORKSCOPE SUMMARY

The Contractor shall provide all things necessajy for the operation, modification, and maintenance of the plant as provided in the operating/Maintenance Manual, and carry out the experimental and developmental operations in said plant as directed by the DOE Technical Project Qfficer.

The operation, modification, and maintenance of the $700 \mathrm{H} . \mathrm{P}$. CTF shall be in accordance with all applicable safety, health codes, standards, and regulations of DOE. The operation, modification, and maintenance shall include the following phases:

a) Phase I - Preparatory work - includes personnel staffing and training, preparation of detailed operating, maintenance, and safety manuals, purchase of tools, spare parts and initial operating supplies.

b) Phase II - Start-Up and Adjustment Period - Check out and activation of all plant systems and subsystems including run-in adjustment and lubrication of all components, chemical cleaning and flushing of systems and lines, and any other activities necessauy to achieve steady-state operating conditions.

c) Phase III - Process Investigation Operations Experimental establishment of the effect of applicable process variables and changes in configuration on plant parameters to determine optimum conditions and configuration for technical, economical and environmental analysis. This includes varying feed rates of consumables, varying temperatures and pressures, and accomplishing plant configuration changes necessary to investigate and all of the operating alternatives outlined in the operating Manual as directed by DOE. 
CONTENTS

I. Progress During This Reporting Period

A. 700 H.P. Combustion Test Facility

1. Operations

a. Second Fiscal Quarter 1978 (April, May, June)

b. Third Fiscal Quarter 1978 (July, August, September)

c. Fourth Fiscal Quarter 1978 (October, November, December)

d. First Fiscal Quarter 1979 (January, February, Macch)

2. Maintenance

a. Second Fiscal Quarter 19:8 (April, May, June)

b. Third Fiscal Quarter 1978 (July, August, September)

c. Fourth Fiscal Quarter 1978 (October, November, December)

d. First Fiscal Quarter 1978 (January, February, March)

3. Modifications

a. Second Fiscal Quarter $19 \% 8$ (April, May, June)

b. Third Fiscal Quarter 1978 (July, August, September)

c. Fourth Fiscal Quarter $19 \% 8$ (October, November, December)

d. First Fiscal Quarter 1978 (January, February, March)

B. 100-20 H.P. Combustion Test Facility

1. Operations

2. Construction and Erection

II. Forecasst Progress

A. 700 H.P. Combustion Test Facility

B. 100-20 H.P. Combustion Test Faci.lity 
I. Progress During This Reporting Period

A. 700 H.P. Combustion Test Facility

This reporting period was spent in Phase I, II, and III. Phase :[ lasted from April 3, 1978 to August 4, 1978. Phase I is preparatory work which includes personnel staffing and training, preparation of detailed operating, maintenance, and safety manuals, purchase of tools, spare parts and initial operating supplies. Phase II lasted from August 4, 1978, to Noveriber 15, 1978. Phase II is Start Up and Adjustment Period - Checking out and activation of all plant systems and subsystems including run-in adjustment and lubrication of all components, chemical cleaning and filushing of systems and lines, and any other activities necessary to achieve steady-state operating conditions. Ihase III started On November 15, 1978, and is still in process. Phase III is Process Investigation Operations.

A complete battery of shake down testing started after the boiler initial fire of August 4, 1978. These facility shake dows tests lasted till November 15, 1978.

The operation limit test started on Noveriber 15, 1978, and was completed on December 15, 1978. The operation limit tests were scheduled to determine the high and low limits of operating variables of the $700 \mathrm{H} . \mathrm{P}$. boiler. The operating variables of the operation limit tests were: No. 6 fuel oil, 30\% com, fuel flow rate, fuel pressure, fuel temperature, air flow rate, atomizing steam pressure, and swirl setting.

The baseline test with No. 6 fuel oil st:urted on December 15, 1978, Data gained from the operation limit testing on \#6 fuel oil was used to analyze results from com testing. The baseline test with \#6 fuel oil was completed by the end of January, 1979, about one week ahead of schedule:

The 30\% com test (effect of coal concentration) started on February 13, 1979. A state boiler inspection was completed on February 5, 1979. The 308 COM test was completed on March 30, 1979.

Several studies were scheduled to occur simultaneously with COM testing. Boiler flame studies under Dr. Mattur of D.O.E. started on January 30, 1979. Erosion, corrosion and deposits testing inside of the boiler started on April 9, 1979, after George Marker and Sons installed three test coupons inside the $700 \mathrm{H.P}$. boiler. 
$\mathrm{SO}_{2}$ emission control testing started on Januäry 27, 1979. Removal of flue gas particulates testing started on January 27, 3.979. Transport properties of COM testing started on February 3, 1979. Investigation involving erosion, corrosion, fouling of piping, and testing valves and met:ers also started on Febuuary 3, 1979.

\section{Operations}

a. Second Fiscal Quarter 1978 (April, May, June)

Facility staffing at the end of June 1978 was $90 \%$ complete.

Facility' steam was used to similate boiler steam production. Facility stearn was used to check out the air ooled condenser, hot well tank, and the deaerator. The site steam reducing station was operationally checked. D.O.E. instrument section calibrated instrumentation associated with the boiler steam production loop while MAISCO was "steaming" the deaerator tank. House steam is supplied at $100 \mathrm{psig}$, and the $700 \mathrm{H.P}$. boiler operating pressure is 175 psig. However, the 100 psig house steam allowed the condenser, hotwell and deaerator to be: operationally checked out.

The COEN Company representative asrived on site on June 12, 1978, in preparation for boiler first fire. The boiler back door firebrick was removed, a complete boiler internal inspection was completed and the back door was reinstalled. On June 15, 19\%8, first fire was ignited in the boiler.

Control panel \#l was received at the jobsite during May. MATSCO personnel helped run conduit to this control panel and enclose an area around the control panel. Seven instrument loops were calibrated for boiler :Eirst fire.

The pulverizer preheater was moved to its centerline and anchor bolts were installed. A \#2 fuel oil line and a natural gas line were rum to the pulverizing preheater.

A proposed safety maniual was turned over to Mr. George Bellas for his and D.O.E. Safety Department approval. Approval was received. 
b. Third Fiscal Quarter 1978 (July, Augrist, September)

By the end of the first week of August, the pulverizer control panel wiring was completed. All pulverizer area motor:s, pumps, etc. were then checked for lubrication and proper rotation. The pulverizer dust oollector nitrogen piping was completed. Mr. Dave Lambeth and Mr. Carl Rahmer from Willians Pulverizer Company and. Mr. Lawrence Burk from QUDAM Controls arrived on the jobsite on Monday, August 14, 1978, for start up of the pulverizing system. During the course of the week, several problems were: enoountered and adjustment modifications were made. On Friday, August 18, 1978, coal was pulverized and a sample was taken. However, during pulverizing, seal hoses and a bushing in the pulverizer were damaged. Further tests were: scheduled for the last week in August to allow replacement parts arrival. These replacement parts were lost by an air carrier, so pulverizer acceptarne was delayed until september. The pulverizer passed acceptance test by D.O.E. and MATSCO during the second week of September. The pulverizer was qualified on Tuesday, September: 12, 1978, at a spinner speed of 715 R.P.M., 92\% pulverized coal went through 325 mesh. At a spinner speed of 600 R.P.M., $98.6 \%$ pulverized coal went through 200 mesh. A pulverizer familiarization course was conducted for MATSCO before Williams Company left the jobsite.

The 7010 H.P. boiler was operated on \#6 fuel oil during the first week of August. During the second week of August, the screw settings on the fuel control valve were checked with a micrometer and these settings were recorded. Joe Ellershaw from COEN had originally set these ten pins. The boiler was fired many times during this week and danper and fuel control valve pin settings were adjusted to bring boiler outlet oxyjen level into proper range. Mr. Chuck MoCann of D.O.E. provided guidance during boiler tuning. During the third week of August, the boiler was operated on \#6 fuel oil on Monday, Tuesday, Wednesday, and Thursday. On Friday, a 25\% COM run was attempted at 50\% boiler load in preparation for the Contractor's Review Meeting of Septeriber 8, 1978. 
Numerous plugging problems hastened the ilecision to cannibalize the fuel train from the 100 H.P. Coal Slurry, to assure 700 H.P. boiler operation during the above mentioned meeting. A successful C CM run during the Contractor's Review Meeting wass obtained and the equipment obtained from the $100 \mathrm{H} . \mathrm{P}$. unit was returned.

Several tours of the facility were conducted during this fiscal quarter. On Friday, September 8, 1978, 30\% COM wass operated in the boiler continuously for three hours for the Contractor's Revilew Meeting. On Friday, September 30, 1978, Mr. J. R. Brill, Director of P.E.T.C. and several D.O.E. personnel were given a facility tour.

c. Fourth Fiscal Quarter 1978 (October, November, December)

The facility shakedown tests were completed on November 15, 1978. The operation limit test started as soon as the shakedown tests were completed. The shakedown tests were spent finding tlie maximum and minimum parameters of the boiler by varying the boiler load, fuel rate, inlet fuel temperature, steam flow, steam pressure, excess oxygen, atomizing steam to fuel pressure differential, furnace pressure, and the swirl setting. With the knowledge gained from the shakedown testing, a battery of operation limit testing with \#6 fuel oil was set up. Data gained fron the operation limit testing on \#6 fuel oil would be used to analyze result: from CoM testing.

On November 15, 1978, the operation limit testing began. Below are listed the completed tests with their completion dates. TEST NO. 700-OPEL-Oil, A0-1 (high load limit) 700-OPEI-Oil, B0-1 (low load limit) 700-OPEL-Oil, Al-1 (air limits at high load) 700-OPEL-Oil, Bl-1 (air limits at low load) 700-OPEL-Oil, A2-2 (atomizing steam limits at high load) 700-OPEL-Oil, B2-1 (atomizing steam limits at low load) 700-OPEI-Oil, B2-1 (atomizing steam low and high limits)

\section{DATE}

Nov. 15, 1978

Nov. 16, 1978

Nov. 17, 1978

Nov. 20, 1978

Nov. 21, 1978

Nov. 22, 1978

Nov. 27, 1978 
TEST NO.

DATIE

700-OPEI-Oil, A3-I (variable high and lon' limits)

Nov. $28, .1978$

700-OPEI-Oil, B3-1 (variable low limits)

Nov. 29, 1978

700-OPEI-COM, BO-1 (fuel low limit)

Dec. 7, 1978

700-OPEI-CCM, A0-2 (fuel high limit)

Dec. 8,1978

700-OPEI-COM, A2-1 (atomizing steam limits at high load)

Dec. 1.2, 1978

700-OPEI-CCM, A2-2 (atomizing steam limits at high load)

Dec. 13, 1978

700-OPEI-COM, B2-2 (atomizing steam limits at low load)

Dec. 14, 1978

700-OPEI-COM, A2-3 (atomizing steam limits at high load)

Dec. 1.5, 1978

The above listed battery of tests concluded the operational limit test.

These tests; were completed on December 15, 1978, on schedule.

The baseline testing with \#6 fuel oil started on December 15, 1978.

d. First Fiscal Quarter 1979 (January, February, March)

Number six fuel oil tests, $30 \%$ COM tests, and $40 \%$ COM tests were conducted during this reporting period.

Below are listed test runs accomplished through the first quarter of 1979. Twenty-nine test runs were completed during January 1979. Seven test runs were completed during February 1979. Eighteen test runs were completed during March 1979.

January

Test Run HINTN-2, Test \#1 Test Run IIJNTN-2, Test \#2

Test Run FINNTN-3, Test \#1

Test Run FINNNN-9, Test \#1

Test Run FINNNN-9, Test \#2

Test Run QASTS-1, Test \#1

Test Run QASTS-1, Test \#2

Test Run ' HNNIN-1, Test \#1

Test Run FINNN-8, Test \#1

Test Run FNNNN-8, Test \#1

Tests 700 BOFASTS, Run No. FNITN-1, Test \#1

Tests 700 BOFASTS, Run No. FNNTIN-1, Test \#2

Tests 700 BOFASTS, Run No. FNNIN-1, Test \#3

Tests 700 BOFASTS, Run No. HNNNN-1, Test \#1, 2, \& 3

Test Run No. HNSNN-1, Test \#I\&2 
Test Run No. HNSNN-1, Test \#3

Test Run 700 BOFASTS, Run FNNNN-6, Test \#1 \& 2

Test Run 700 BOFASTS, Run FNNNN-6, Test 3

Test Run No. FNSNN-1, Test \#1

Test Run No. TNNNN-1, Test \#1, 2, \& 3

February

Test No. 700-C3FASTS, Run No. QNINNN-1

Test No. 700-C3FASTS, Run No. HNSNN-2

Test No. 700-C3FASTS, Run No. HNNNN-2

Test No. 700-C3FASTS, Run No. HANNN-1

March

Test No. 700-C3FASTS, Run No. FNSNN-2, Teist \#1, 2, \& 3

Test No. 700-C3FASTS, Run No. HNINTN-I, Test \#I\& 2

Test No. 700-C3FASTS, Run No. FNNTIN-1, Test \#1

Test No. 700-C3FASTS, Run No. TNNNN-5, Test \#1, 2, \& 3

Test No. 700-C3FASTS, Run No. FNNNS-1, Test \#1 \& 2

Test No. 700-C3FASTS, Run No. FASNN-1, Test \#I \& 2

Test No. 700-C3FASTS, Run No. FNNNN-2, Test \#1

Test No. 700-C3FASTS, Run No. TANNN-1, Test \#1

Test No. 700-C3FASTS, Run No. FANNN-1, Test \#I

Test No. 700-C3FASTS, Run No. TNNNN-1, Test \#1

Test No. 700-C3FASTS, Run No. TNNNN-3, Te:st \#1

Dr. Mathur of D.O.E. conducted flame studies during this quarter. Isokinetic and high volume sampling also took place during this quarter. Problems encountered during this period of testing are listed below.

2. Maintenanos

a. Second Fiscal Quarter 1978 (April, May, June)

During system checkout, the $60 \mathrm{H} . \mathrm{P}$. stack blower motor failed. A $40 \mathrm{H} . \mathrm{P}$. motor was located, installed, and put into service as the driver for the stack blower. New sheaves were installed on the 40 H.P. motor to slow the fan speed from 1,542 R.P.M. to 1,330 R.P.M. The 60 H.P. motor was repaired under warranty.

The two building main sump pumps were installed and put into service after the main sump was drained and cleaned. 
Various pumps, motors, blowers throughout the 700 H.P. Combustion Test Facility have been checked out for operation. These pieces of equipment have been aligned, doweled; oiled, greass:d, leveled, belt tension checked, bump checked, and certified for operation.

A basic inventory of tools has been jurchased. Concentration of tool procurement was toward items needed for sitart up.

A preventative maintenance file has heen started. Complete vendor specifications on each piece of equipment will. be maintained in each file. Items needed like type of oil and tools required to pull preventive maintenance on each piece of equipment will be listed on that piece of equipment's individual file.

Periodically, group instruction has been conducted on various systems. Flow patterns, valves, temperatures, presisure, control, and particulars of each system are pointed out in these instruction sessions. Theoretical instruction was followed by actual "on sight" tracing of systems.

b. Third Fiscal Quarter 1978 (July, August, September)

The fuel oil metering valve measuring \#6 fuel oil going into the proportioning feeder tank was received and installed by the building contractor. During calibration and start up of this metering valve, it was ciscovered that an internal cogwheel installed at the factory was incorrect. New gears and push buttons were air freighted to the jobsite and installed. After calibration and checkout, the fuel metering valve operated correctly with less than a $1 \%$ error across the complete flow range.

The installation of the relief valve for the steam jacket around the slurry hold tank is complete. Its vent to atmosphere is complete. A sight glass has been installed on the slurry hold tank so its level oould be determined. 
Pressure gauges were installed on the: inlet and outlet of the air coled condenser during September. All blades in both oondenser fans were pitch checked and verified at approximately $8^{\circ}$.

Previous oil runs were accomplished prior to July without the bags in the flue gas baghouse. One hundred and twenty baghouse bags were installed in July.

c. Fourth Fiscal Quarter (Octaber, Noveniber, December)

Full steam flow problems were encount:ered during the initial segment of this quarter. The air cooled condenser was limiting boiler output to below its nameplate of $24,000 \# / \mathrm{hr}$. To increase: steam flow, the air cooled condenser fan blades pitch was changed from $8^{\circ}$ to $12^{\circ}$. A blow off vent muffler also has been installed beside the oondenser to help the boiler reach full load. A sight glass was installed in the condenser water side manifold to check for condensier tube flooding during operation. No condenser flooding was noted.

Because the deaerator tank has been in operation for several months, startup and operation problems have been ironed out of this system. So that water analysis can be performed, a D.A. tank sample cooler has been fabricated, installed, and is operational. The I" Siuroo regulator valve was replaced with a 2" regulator valve for more flow. The D.A. tank had an internal inspection during this quarter, and no defects were encountered.

A solenoid valve controlling steam flow to the fuel oil pump suction heater was inoperable, so it was troubleshot and replaced. On Friday, October 13, 1978, oil was noticed coming out of the condensate line from the \#6 fuel. oil storage tank internal heater. In orcler to repair this leak, approximately 14,000 gallons of fuel oil were removed from the tank. The leaking internal heater line was repaired, hydrostatically tested, and put back into service. 
A 100 gallon \#6 oil spill occurred during the week of November 27, 1978, while refurling the fuel oil storage tank. A flexible hose burst during the refueling operation. MATSCO aided the oil company and their oil spill cleanup crew in oil cleanup. A new proa:dure for unloading oil was written and approved by all concerned parties.

During initial installation, incorrest agitator blades were installed in the slurry mix tank and the slurry hold tank. The proper size agitator blades were installed in both tanks after receij:t from the vendor.

Coal was pulverized several times in November and December. An average of $90 \%$ through 200 mesh was obtained by the pulverizer. The gravimetric feeder was disassembled, trouble shot, repaired, and put back into service. Both the gravimetric feeder and the fuel oil metering valve were calibrated during the fourth fiscal quarter.

The sodium bicarbonate injection system was started up and operated during this fiscall quarter. Before startup, the rotary valve vent had to be plumbed in and a new $\mathrm{NaHCO}_{3}$ funneling casing had to be machined. Using the sodium bicarbonate system and the delta - P manimeter across the baghouse, the baghouse bags can be coated to a predetermined level for bag protection. d. First liscal Quarter 1979 (January, l:ebruary, March)

A state boiler inspection was perfonmed on Monday, February 5, 1979, with good results. A copy of the inspection report was given to Mr. Rich Cimino of the D.O.E. safety office.

An "Electro-Mag" electromagnetic water conditioning system has been installed in the boiler water feed line between the boiler feed pump and the boiler. Experience to date with this new piece of equi.pment has been pleasant. No sulfate or phosphate chemicals have been used after the installation of the "Electro-Mag". The conductivity is controlled to a maximum of 3,500 micro-mhos by surface and bottom blows. 
A suitiable method of attaching flame study targets inside of the boiler has been found, so flame study targets stay in place longer. Mondays have been designated as a maintenance day. The 700 H.P. boiler is cool enough after the weekend oool down to allow the target's to be changed each Monday.

Additional outside steam trace couplings have been installed. These additional couplings will assist in thawing out of the steam trace lines in case of another freeze up as occurred on January 3, 1979.

\section{Modifications}

\section{a. Second Fiscal Quarter 1978 (April, Miay, June)}

An additional sump punp has been installed in the below floor recess directly under the Williams Pulverizer to alleviate the existing water problem on the pulverizing room floor.

The stack dampening valve has been moved from between the baghouse and stack blower to between the boiler and the flue gas cooler to help resolve the boiler pressure-vacuum draft control prololems. Several manometers were installed throughout the boiler flue gas system to monitor pressure drops across several pieces of equipment.

Several noise complaints were received while the stack blower was in service. The stack blower has been completely insulated and its operation is kept to a ininimum.

Several piping jobs were undertaken ky MATSCO to assist completion of construction and minimize startup time. The sight glass blow down, sight glass housing blow down, water flow regulator blow down, steam drum blow down, water softner, steam heater, soot blower, and water feed pump gland drains were piped in.

Before startup, all boiler tubes were checked for obstructions and found to be clear. A letter was received from Nebraska Boiler Company via Hoffman Engineering acknowledging gouges on outside wall of several tubes. Nebraska pointed out that these gouges would not affect the operation of the boiler. 
An external platform has been attachid to the CTF building. This platform surrounds the flue gas line between the boiler and the flue gas line. This platform will be used as a sampling point: for isokinetics and the high volume sampler.

b. Third Fiscal Quarter 1978 (July, Augrist, September)

Several modifications have been incorporated around the 700 H.P. boiler in preparation for the test program and flame studies. Two one foot square windows have been cut in the CTF north will behind the boiler rear abservation windows. These two holes will allow probes to be inserted into the aft end of the boiler through the observation windows. A penetration into the main steam outlet was completed and a steam calorimeter has been installed. Two 0-300 psi gauges have been installed on the copes drum level controller sense lines. The boiler atomizing steam line has been replumbed to provide 175 psig steam instead of 100 psig. George llarker and Sons installed three sight glasses into the boiler for flame studiesi. Ten outside skin temperature thermocouples were installed on the boiler skin. Top decking and handrails were installed on top of the boiler to aid personnel in the operation and maintenance of the boiler.

The temporary wooden control room pariels were removed and installation of the pernanent control room was started during this fiscal quarter. After completion, the ground floor control room will control the $700 \mathrm{H} . \mathrm{P}$. boiler, and the piggyback second floor control room will control the $100 \mathrm{H.P}$. and the 20 H.P. boilers.

Several non-related modifications to the facility were accomplished during this quarter. Installation of a D.A. tank relief valve and its vent to atmosphere were completed. A hotwell tank inlet line thermometer and a hotwell pressure gauge have been installed. The high bag area vent fans have been installed and are operational. A personnel safety shower and personnel safety eyewash have been installed in the Combustion Test Facility. 
c. Fourth Fiscal Quarter 1978 (October, November, December)

Several additional modifications were made to the 700 H.P. boiler during this fiscal quarter to accommodate flame studies. A 5 " $\times 12$ " instrument port was installed on the east side of the bo:iler. Three flame study targets were installed in the boiler on centerline dijectly across from the three sight glass locations. A track has been fabricated below all sight glasses so optical instrumentation could be moved on a portable table to all sight glass locations.

During this quarter, paint was notiasd to be blistering on the outside skin on the boiler convection upper side casing below the steam drum when the boiler was at high fire. The Nebraska Boiler Company sent out a welder on November 1, 1978. This first repair by Nebraska was not sufficient because when the combustion air blower was turneil on, the boiler casing leaked air. Nebraska was recontacted and sent Mr. Jolın Gimis and Mr. Wes Wilson out on November 10, 1978. Repairs were made to the boiler convection upper side casing below the steam drum. Refractory and skin sheeting were installed on the drum per ASME code by a certified welder. The boiler was ready for operation on Saturday, November 11, 1978.

A new "Chromolox" electrical heater for \#6 fuel oil/COM was plumbed into the boiler fuel train aft of the existing fuel steam heater.

The bags in the baghouse have been replaced twice during this three month period. To preserve the bags as much as possible, start up operating procedure calls for the bags to be sodiun bicarbonate coated before fire is lit in the boiler. A flyash removal chute has been installed after the rotary air lock below the flue gas baghouse. $\mathrm{A} \mathrm{CO}_{2}$ fire extinguishing system has been added to the flue gas baghouse in case of an unoontrollable fire. A pressure differential manometer has been installed across the baghouse so bag buildup can be determined. 


\section{d. First liscal Quarter 1979 (January, J'ebruary, March)}

In order to assist flame studies, thermocouples were installed at sixteen different locations inside of the boiler. The first bank of eight thermocouples is 5 feet from the boiler back wiall, and the second bank of eight thermocoup.les is 7 feet from the boiler back wall. A local digital readout is located outside of the boiler, and thise 16 readings are recorded during test runs.

Streamlining of the fuel train and flul oil steam heater is in progress. Streamlining of the piping will help minimize frictional losses. One inch "Swagelok" fittings and one inch tubing $(I D=.810 ", \mathrm{OD}=1.000 ")$ are being used to streamline pipe ID and eliminate elbows. The elbows are being replaced with large constant radius tubing bends.

Startup and calibration of the $\mathrm{NaHCO}_{3}$ injection system was completed during January, 1979. A variable speed vibrator has been installed on the sodium bicarbonate storage bin. A NaHCO; storage tank drier has been installed to keep the chemical dry while it: is in storage. Immediately after startup and calibration of the $\mathrm{NaHCO}_{3}$ system, its rotary airlock feed valve failed and a replacement valve was ordered. A portable sodium bicarbonate system has been used when available to iriject $\mathrm{NaHCO}_{3}$ into the flue gas system. Data has bien collected to calculate the efficiency of sulfur dioxide removal.

The coal oil mixture test loop is progressing toward completion. Five Ron-Petcos, four thermocouples, and a siudge density meter have been installed in the test loop. Electrical, tubing plunbing and installation of transmitters are progressing.

\section{B. 100-20 H.P. Combustion Test Facility}

The 100 H.P. test facility came under Contract No. EW-78-C-02-4740 on July 15, 1978. The original 100 H.P. test facility was located near the main boiler house at the main gate of Pittsburgh Energy Technology Center. This section of the report will not cover a full year. It will cover July 15, 1978 to April 1, 1978. 
- Previous reporting on the original 100 H.P. test: facility can be found under contract No. EY-76-C-02-4049. After July 15, 1978, the original $100 \mathrm{H} . \mathrm{P}$. test facility operated for approximately three months. After this three months of operation, the original 100 H.P. test facility was abandoned and construction of the new 100-20 H.P. test facility began. MATSCO personnel who operated the original 100 H.P. test facility were moved to the new 100-20 H.P. test facility area to begin construction. This section of the report on the 100-20 H.P. combustion test: facility will be broken into two areas: 1. Operations (original 100 H.P.), and 2. Construction and Erection (new 100-20 H.P. test facility).

\section{Operations (original 100 H.P. boil.er)}

The operational phase of the original 100 H.P. boiler under contract No. EW-78-C-02-4740 began on July 15, 1978, and officially expired on September 29, 1978. The majority of testing was accomplished previous to this time under contract No. EY-76-C-02-4049.

Several tasks were accomplished during the remainder of July. MATSCO supplied support to the Bureau of Mines personnel in linking up the 100 H.P. main steam outlet to the main boiler house main steam line. The main boiler house was in a "down condition" and steam was needed for atomization for the 700 H.P. boiler operation. After the link up to the main steam header, the original 100 H.P. boiler supplied atomizing steam for 700 H.P. boiler operation. A NATSCO built baghouse was installed and removed during the latter part of July. This baghouse was on the stack and was used to calculate ash balance. The last week of July, 1978, was spent testing the original $100 \mathrm{H} . \mathrm{P}$. on $20 \%$ oal oil mixtures at various loads. The original 100 H.P. boiler electric fuel oil heater was cannibalized for the fuel train of the 700 H.P. combustion test facility.

The majority of work accomplished by the original 100 H.P. operations crew during August was in support of the 700 H.P. combustion test facility. The 500 H.P. pulverizer was used to pulverize coal for both the 700 H.P. and the original 100 H.P. boilers. The 100 H.P. operations crew overhauled the 500 H.P. pulverizer. MATSCO personnel poured a concrete pad, and a high volume blower was 
installed on this pad at the original $100 \mathrm{H.P}$. boiler. The'stack baghouse was reinstalled for further ash balance tests. The D-1, S-1, and T-1 burner assembly was installed on the 100 H.P. boiler for testing. The original 100 H.P. boiler fuel train was cannibalized for use in the $700 \mathrm{H} . \mathrm{P}$. boiler fuel train.

September, 1978, was the final month of operation for the original $100 \mathrm{H} . \mathrm{P}$. boiler. The $100 \mathrm{H} . \mathrm{P}$. operations crew pulverized coal for operation of the 700 H.P. boiler. The cannibalized fuel train was replaced on the $100 \mathrm{H} . \mathrm{P}$. boiler. All fuel pipes were flushed in preparation for use of SCR II fuel. Four tests were run using SCR II fuel. 'Jhe remaining two weeks of September were spent in disassembly, removal of parts and scrapping of the original 100 H.P. facility. Several parts and insitruments were saved in the event they could be reused. The operating personnel of the original $1.00 \mathrm{H} . \mathrm{P}$. boiler were reassigned to the new 100-20 H.P. boiler combustion test facility on September 29, 1978.

2. Construction and Erection (new 100-20 H.P. test facility)

After scrapping of the old 100 H.P. Facility, MATSCO personnel were reassigned to construction of the new 100-20 H.P. Combustion Test Facility. The new 100-20 H.P. boilers and ancillary equipment are located in Building \#93 at the Pittsburgh Energy Technology Center. The 7010 H.P. Combustion Test Facility is also housed in Building \#93. MATSCO personnel comitted all man hours toward construction after October 2, 1978.

A double deck control room was erected by the 100-20 H.P. Operations crew. The first level control room is ussed for the $700 \mathrm{H.P}$. conbustion test facility. The second level control room will be used to control. the 100-20 H.P. Combustion Test Facility. Tile floors, air conditioning, hidden electrical wiring, emergency lighting and false ceilings were installed in the double deck control room. A circular staircase leading up to the second level control room has been installed. 
Additional floor drains for the new 1.00-20 H.P. boilers have been installed in Building \#93. The additional floor drains were tied into the building existing drains, Oil spill caps have been falsicated for all floor drains.

The 100 H.P. boiler was received on site during the week of October 30 , 1978. The 100 H.P. boiler platform has heen erected, and the boiler is on this platform on centerline in the building. Personnel handrails and walkways around the platform and boiler have been completed.

The electrical transformer pad and its transformer have been installed in Building \#93. This transformer will supply power for operation of the 100-20 H.P. combustion test facility.

The 20 H.P. boiler was received on site on January 29,1979 . The 20 H.P. boiler platform has been erected, and the boiler is on this platform on centerline in the building. Personnel hindrails and walkways around the platform and boiler have been completed.

The fuel oil storage tank, slurry mix tank, slurry hold tank and the bag house have been received and placed on their respective center lines. Piping drawings were received during the month of March from Slogan Engineering, and piping installation has started. Piping hanging from the mezzanine level will not be assembled until the mezzanine is complete, but all other piping installation is planned.

New fire doors have been hung in the facility to meet fire standards. The lower control room north door was replaced with a fire door. The 100-20 H.P. machine shop door was replaced with a fire door. The 700 H.P. boiler room - MHD door was replaced with a fire door.

The suoply lines for soft water, steim, \#6 fuel oil, and \#2 fuel oil have been plumbed through the firewall between the 700 H.P. boiler room and the high bay area in preparation of joining by the 100 H.P. \& 20 H.P. boilers. 
Various conduit and wireways have bet:n installed throughout the 100-20

H.P. facility. The motor control center has been installed on its pad.

Electrical wire pulling has been accomplished through the majority of conduit and wireways, Facility fluorescent lights have been changed over to mercury vapor lights.

Various pumps-motors throughout the facility have been grouted into position. Plumbing and electrical connections to tiese pumps-motors have been started.

\section{Forecast Progress}

A. 700 H.P. Combustion Test Facility

Forecast progress for the $700 \mathrm{H} . \mathrm{P}$. Combustion Test Facility oovers several areas. Two 500 hour tests are scheduled in the near future. One test will be using an emulsifier and the other test will be without: emulsion. Approximately three months of testing is scheduled to determine effect of coal particle size. Additional testing on the above perameters is forecast using defferent types of coal. Pittsburgh seam coal has been used for the test program to date.

Flame studies and erosion-corrosion studies will continue throughout the complete testing program. These studies are presently underway. $\mathrm{SO}_{2}$ emission control, removal of particulates, and transport properties of COM will continue throughout the complete testing program. These studies are also presently underway. B. 100-20 H.l?. Combustion Test Facility

Forecast progress for the 100-20 H.P. Combustion Test Facility covers completion of construction, startup, adjustment, and test program operation. Construction activities should terminate by the first of August 1979 in preparation for startup activities. Facility checkout, startup and adjustments are scheduled to be complete by the end of September 1979. After facility checkout is complete, the test program will start for both the 100 H.P. unit and the 20 H.P. unit. 